\title{
Trends Of Changes In The Polish Industry Innovativeness (Against The Background Of Leading World Economies)
}

\author{
Adam Mazurkiewicz, (Email: Adam.Mazurkiewicz@1tee.eadom.pl), Institute for Terotechnology, Poland
}

Rozalia Sitkowska, Institute for Terotechnology, Poland

\begin{abstract}
Tendencies concerning innovativeness changes in selected sectors of the Polish economy were identified in the paper. The trends were depicted against the background of the USA, Japan and the $E U-15$ and they comprised: public and business financing of the $R \& D$ area with reference to GDP, $R \& D$ expenditure per capita, and venture capital funds supporting innovations commercialization. The observed correlation between the financing level of the $R \& D$ area and the innovativeness level of the US economy made the basis for the analysis conducted. The analysis concentrated on trends occurring in the Polish economy in the context of industry innovativeness, in particular processing industry, including the sector of investment goods. Conclusions resulting from the analysis of innovation commercialization processes with venture capital funds were presented. Countermeasures which were taken in Poland to prevent the marginalization of financing the $R \& D$ area were demonstrated as well.
\end{abstract}

\section{INTRODUCTION}

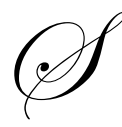

ince the beginning of the Polish economy transformation in 1989 the innovativeness issue has been a very important element of strategic analyses on the national scale.

The idea of combining national economies of the EU countries, adopted along with the assumptions of the Lisbon Strategy, foresees ${ }^{1^{*}}$ the creation of an economic area in Europe that would be competitive for the most dynamically developing world economies, in particular the USA and Japan.

A new approach to innovations management in the European Union is influenced by the following factors: market globalization, growth of the importance of strategic alliances of economic subjects, the emergence of companies, especially from Asian countries, that are very competitive in respect to their high technological and economic level, growing internationalization of enterprises, scientific research and innovative activity, more and more intensive overlapping interferences between science and advanced technologies, growing costs of research exceeding the possibilities of individual industrial organizations, regions and even the whole economies, and growth of the importance of environmental protection.

The paradigm of economic development, that has been in force until recently, assumed that the market mechanism plays the most important role in innovativeness stimulation [5].

At the same time the high importance of innovative activity in the development of companies, regions and particular countries requires changes in the procedures of developing national innovation systems. The innovative

*On $2^{\text {nd }}$ February 2005 the European Commission proposed part verification of this assumption 
activity cannot be left exclusively to the regulatory function of the market, it should be influenced by state authorities and supranational economic organizations. Such an approach is expressed in the Lisbon Strategy, in the EU Framework Programs and in case of Poland in the National Development Plan for the years 2007- 2013.

When comparing the assumptions and the results achieved within the realization of the Lisbon Strategy so far and with reference to the current situation of the Polish economy in the $R \& D$ area the presence of negative tendencies concerning the innovativeness development in Poland becomes evident: the national science is relatively strong but not perceived as an attractive partner by the industry, there are no system stimulators increasing the innovations absorbency of the economy, and the innovativeness of the Polish economy becomes more and more dependant on imported patents, machine licenses and advanced technologies.

The authors of the paper analyzed strategic indices of innovativeness in the Polish economy, such as: the amount of R\&D expenditures, expenditures per capita, share of high risk venture capital against the background of selected leading world economies and next they identified the observable trends.

\section{ANALYSIS OF NOMINAL EXPENDITURES ON THE R\&D ACTIVITY}

The amount of R\&D expenditures from public funds both in the USA and the EU has maintained at a comparable level of about $0.25 \%$ GDP for over 10 years and since 1989 a constant, although not very significant decreasing tendency can be observed (fig. 1).

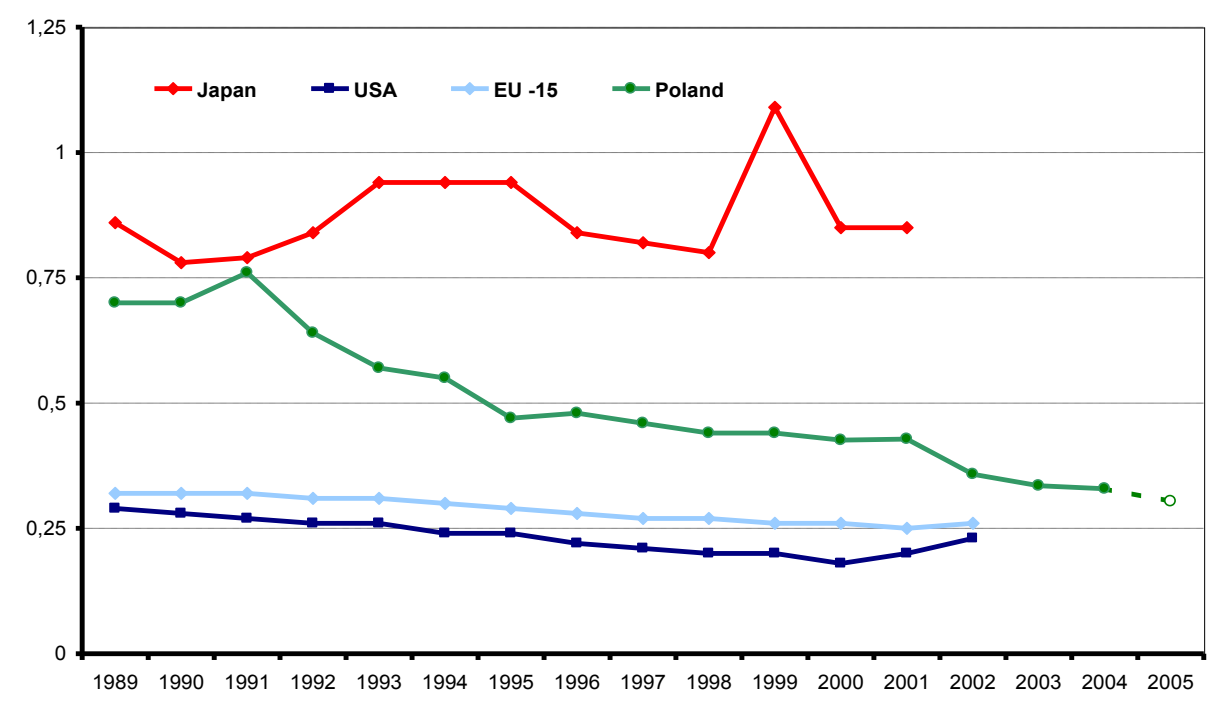

Fig. 1: Public (Governmental) Expenditures on R\&D (in \% of GDP) in Selected Countries

Source: Own analysis on the basis of [1,7]

Poland against the background of the average of the EU-15 and the USA was characterized by a significantly higher level of R\&D expenditures stemming from the budget, although a significant decrease of financing the innovativeness development in this financial aspect could be seen in the recent years. The percentage share of the state budget financing in GDP declined in Poland systematically from the level of Japan, i.e. about $0.75 \%$ of GDP at the beginning of the nineties and recently it has reached the same level as the EU-15 and the USA possess, i.e. $0.25 \%$ of GDP. However, the lack of public funds for research in Poland has not been replaced by financing of innovativeness coming from business (fig. 2). 
A different trend has been observed in the US economy, where after 2001 over $10 \%$ growth of the state budget expenditure for R\&D financing could be observed. It was the reaction of the USA to negative changes in strategic characteristics of country innovativeness, the result of which was the decline in business expenditures on R\&D (fig. 3).

The US governmental intervention in 2002 that increased the public expenditure for R\&D by $0.03 \%$ of GDP constitutes, with reference to the previous year, an insignificant growth of percentage share of public funds for research in the USA, however in the nominal dimension it exceeds the yearly expenditure for R\&D activities borne for example by Slovenia, Slovakia or Romania.

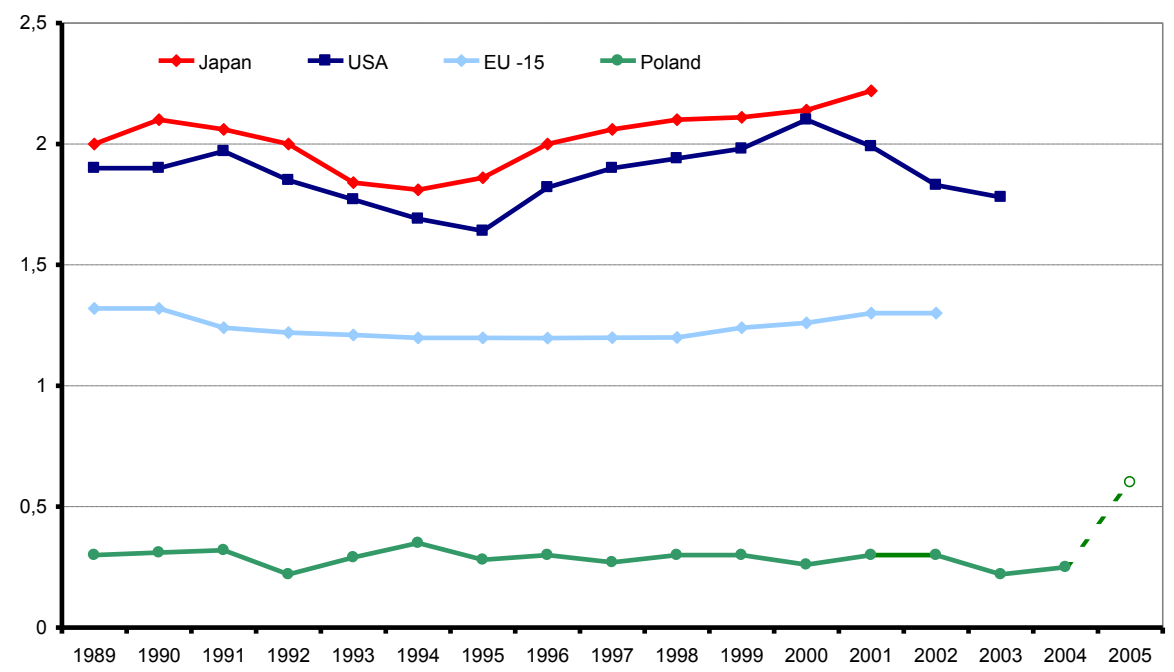

Fig. 2: R\&D Expenditure Financed by Business (in \% of GDP), So-Called BERD Source: Own analysis on the basis of $[1,7]$

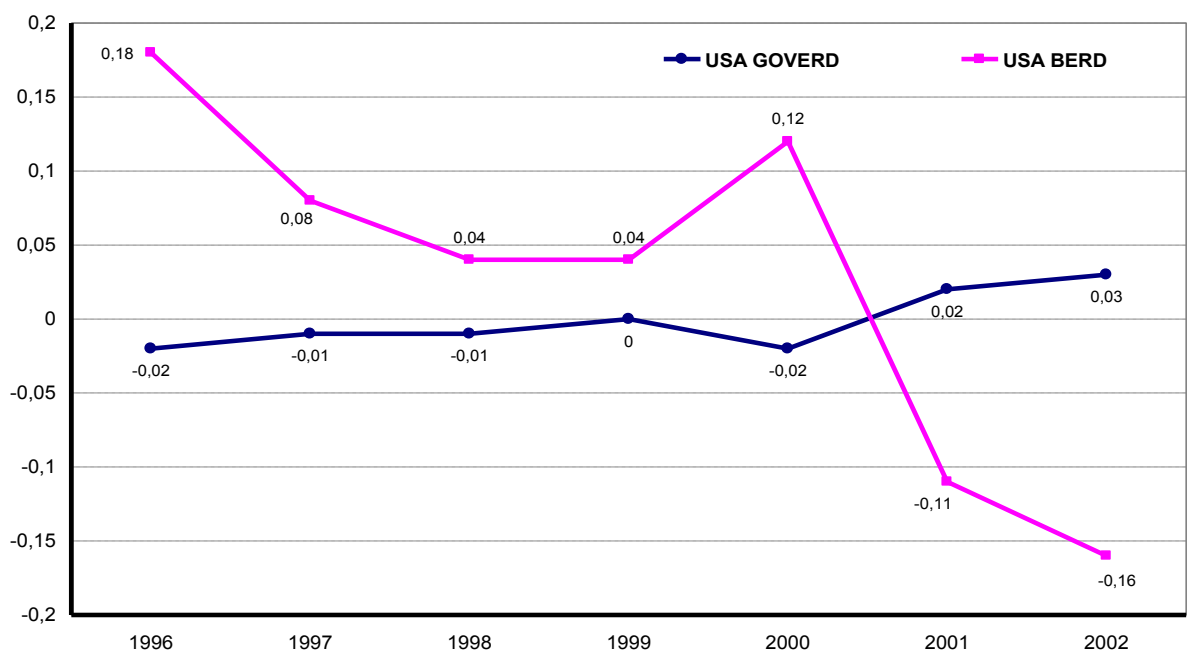

Fig. 3: Dynamics of Yearly R\&D Expenditures Growth (in \% of GDP) Financed by Business in Comparison with Expenditures Growth Financed by the US Budget (the Previous Year - 100\%) 
Tendencies observed in the United States had no equivalent in the EU economy, where the dynamics of changes in public and business financing has remained at the same, very stable level (fig. 4).

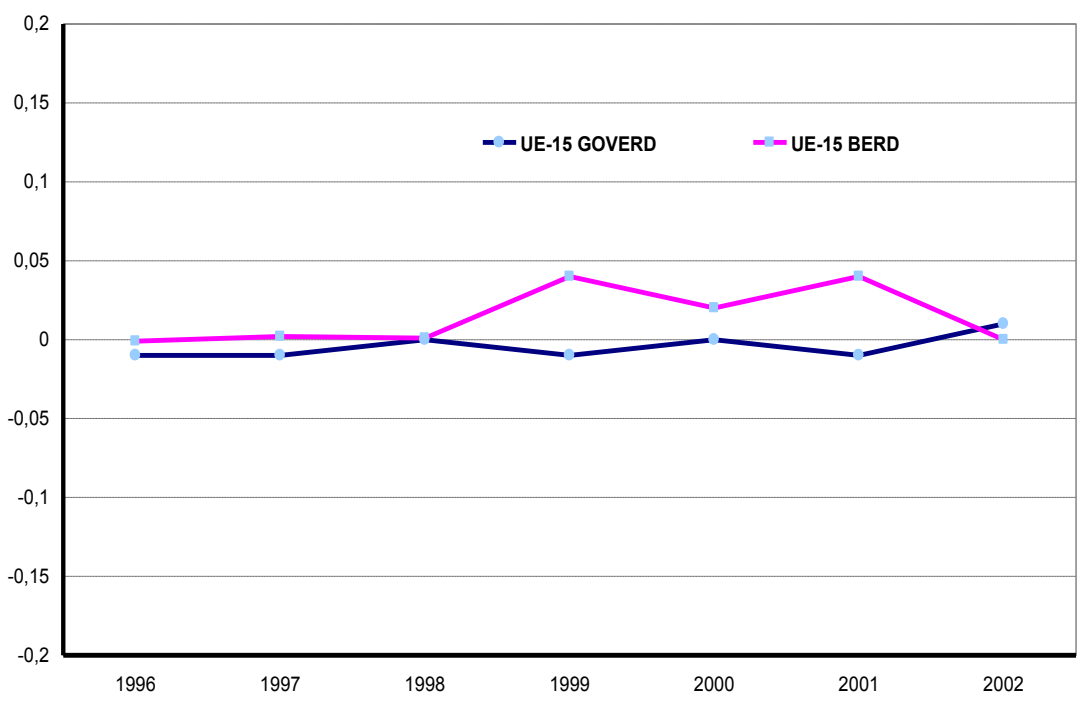

Fig. 4: Yearly Growths of R\&D Expenditure (in \% of GDP) Financed from Business in Comparison with Growths of Expenditure Financed from the EU-15 Budget

Source: Own analysis on he basis of $[1,7]$

In Poland, a significant increase of business financing of innovations was observed in 2004, however, a really great jump of this type of financing is planned and expected in 2005 (fig. 5).

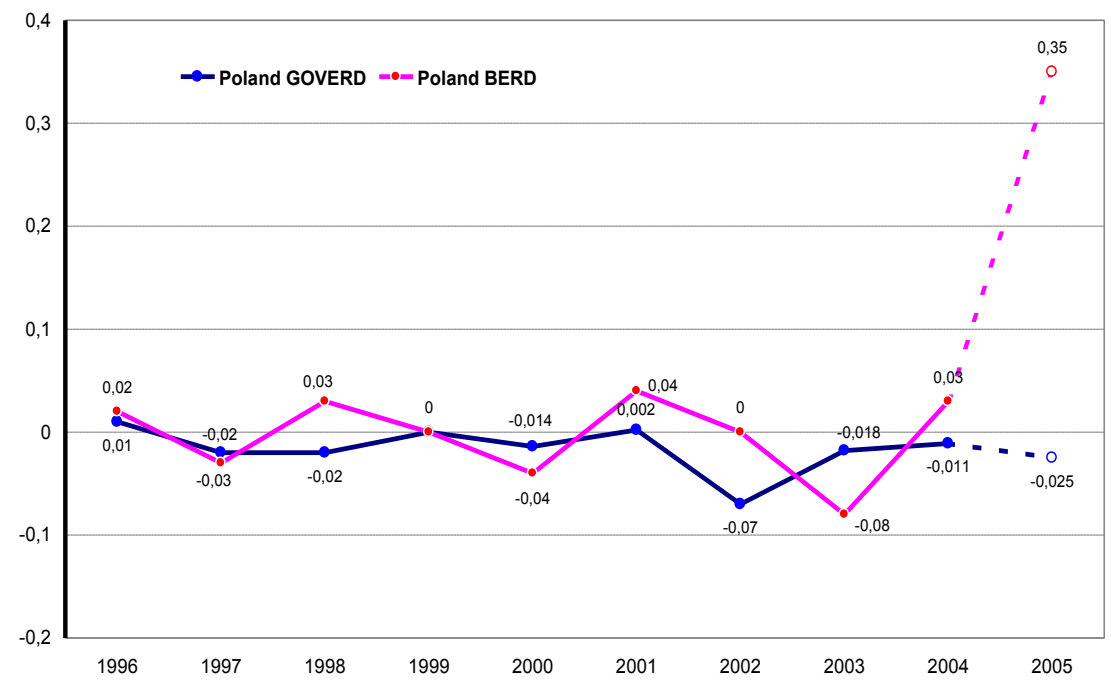

Fig. 5: Yearly Growths of R\&D Expenditure (in \% of GDP) Financed from Business in Comparison with Growths of Expenditure Financed from the Budget in Poland

Source: Own analysis on the basis of $[1,7]$ 
The comparison of financing stemming from business in Poland, the EU and Japan, with reference to the United States, was presented by means of BERD indices in percentage terms in fig. 6.

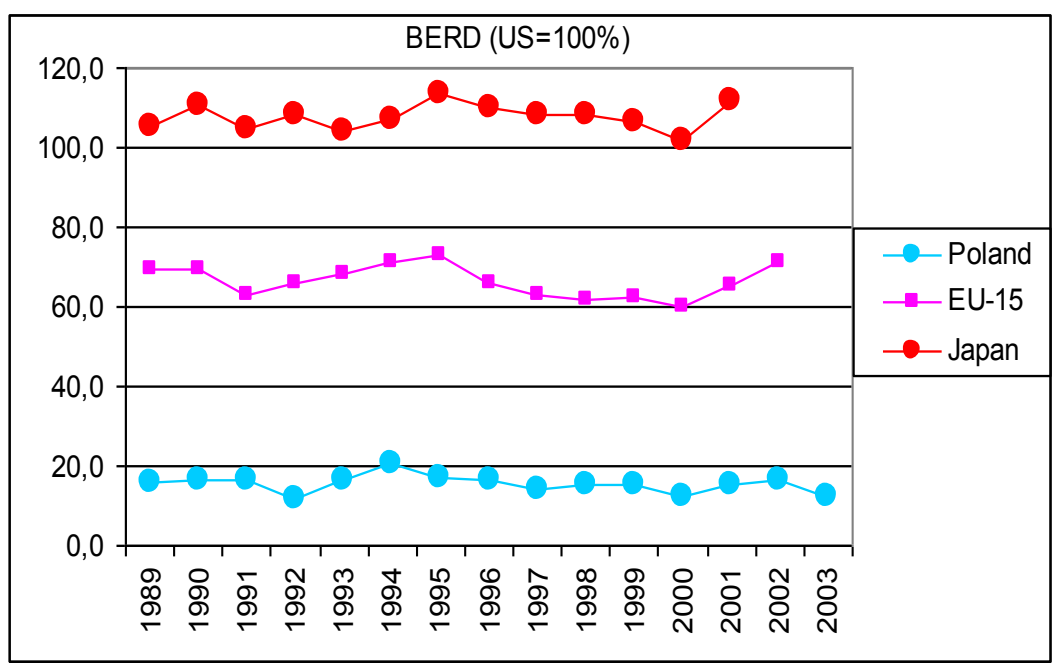

Fig. 6: The Level of Financing the R\&D Area from Business in Poland, the EU and Japan, with Reference to the United States

Source: Own analysis

In the period 1989-2003 the average level of non-budgetary (business) financing of the R\&D area in Poland amounted to little over 15\% and in the year 2003 it went down even to $12.3 \%$ (when referring to the United States).

The observation of the trend of lowering business financing of the R\&D area in the Polish economy should make the Polish government start immediate state interventions aimed at the stimulation of innovations in the economy through financial support for the R\&D area, especially that the Polish government is obliged to do it through the agreements with the EU concerning the aggregate growth of financing the research (up to 3\% of GDP in 2010) which were included in the Lisbon Strategy. Unfortunately the complex financing of the R\&D area in Poland, both from public and business means, till year 2003, shows a constant downward tendency.

The comparison of general financing of R\&D in Poland, in the EU and Japan, with reference to the United States, when using GERD indices in percentage terms, is shown in fig. 7.

As it follows from the presented analysis Japan clearly dominates among the leading world economies, as far as the level of financing the $R \& D$ area from the state budget is concerned. At the same time its share of financing the R\&D development from business remains similar to the US share. The situation of Poland seems to be very unfavorable, when taking into consideration the two above characteristics. Its R\&D financing stemming from the state budget remains, in relation to similar expenditure borne by the United States, at the level of 20\%. Moreover, in Poland a tendency of systematic decrease of public financing can be observed that is to be stopped until 2006. 


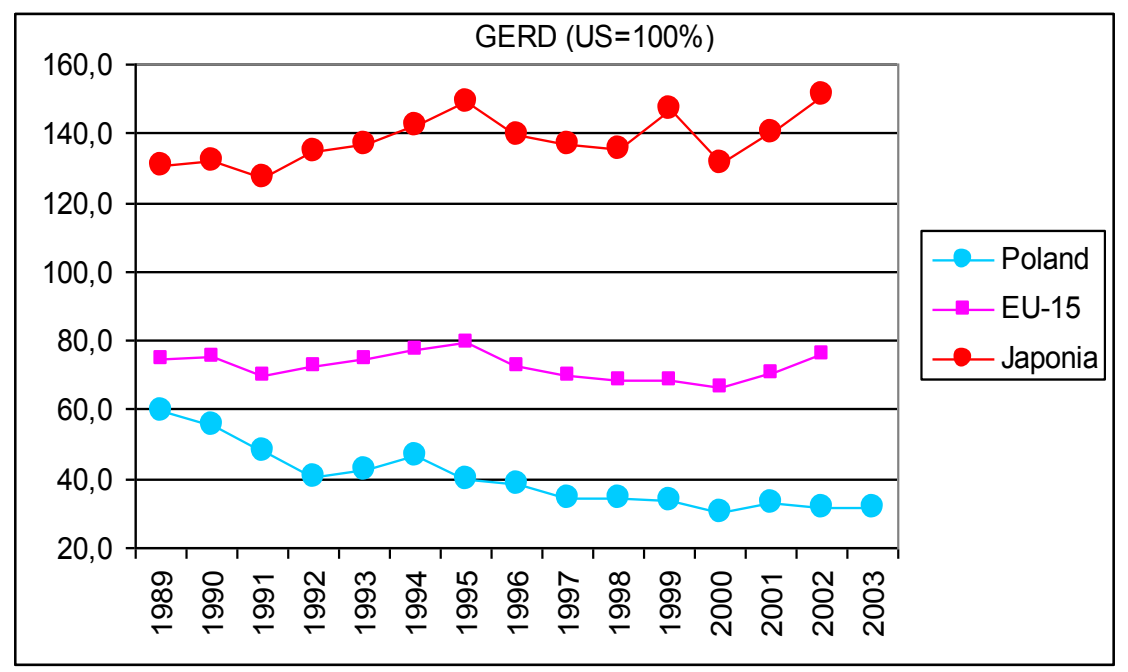

Fig. 7: The Level of General Financing of R\&D in Poland, in the EU and Japan, with Reference to the United States

Source: Own analysis

\section{ANALYSIS OF EXPENDITURE ON R\&D ACTIVITY PER CAPITA}

From a statistical point of view financing the innovativeness development can also be considered in the context of the amount of financial means allocated for the R\&D activity per inhabitant (fig. 8).

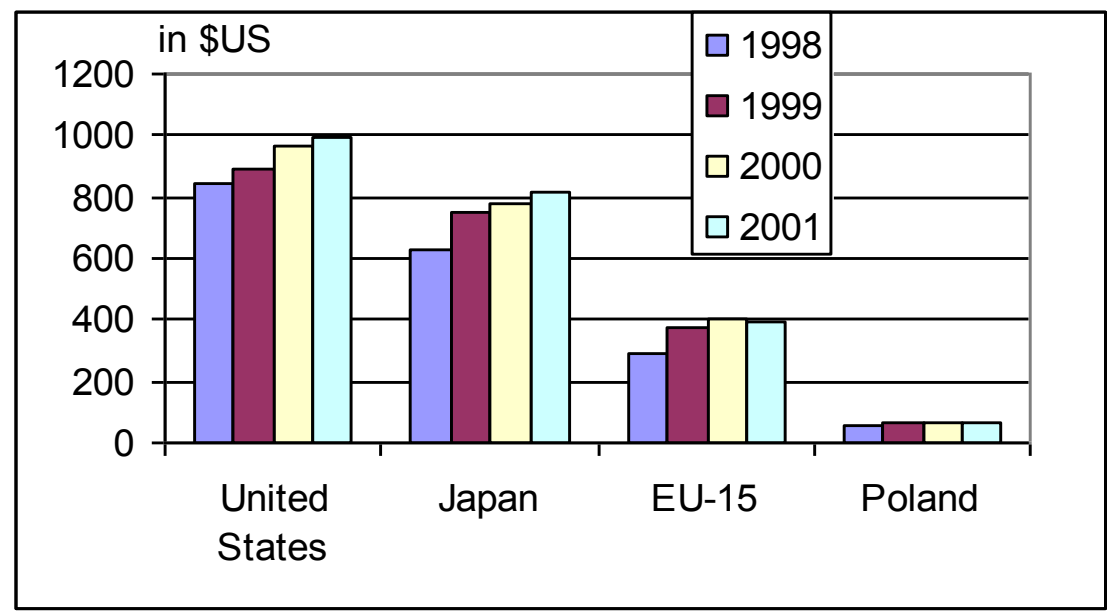

Fig. 8: Expenditures on R\&D per Capita in PPP\$

Source: Own analysis on the basis of data from the Central Statistical Office (GUS) in Poland

In the case of this index and taking into consideration nominal expenditures, a clear dominance of the USA in relation to competitors from the European Union and Japan can be seen. Additionally a significant constant growth of absolute value in financing the R\&D per capita in the last years can be perceived. 


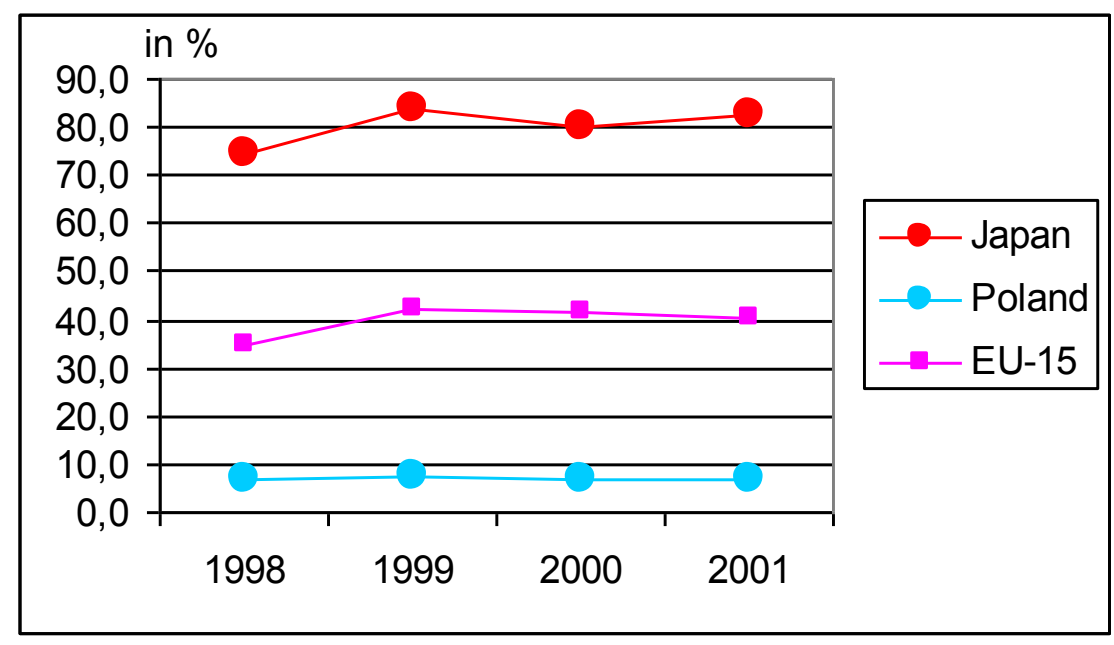

Fig. 9: Expenditures on R\&D per Capita (USA =100\%)

Source: Own analysis on the basis of data from the Central Statistical Office

(GUS) in Poland

Assuming the expenditure level on R\&D per inhabitant in the USA as $100 \%$ it can be stated that the financing level in Poland remains below 7\%. It is one of the main reasons why the innovativeness level of Polish economy, in particular the industry, is not satisfactory. In Japan the expenditure level on R\&D per capita is 12 times higher than in Poland, but $18 \%$ lower than in the United States (fig. 9).

\section{COMMERCIALIZATION OF INNOVATIONS THROUGH RISK CAPITALS}

Apart from the level of expenditure on R\&D presented above, the growth of innovativeness is determined by many other factors, among others: by the access to advanced technologies, including purchase of licenses, by the potential of innovative activity structures, by technological level of the economy, including the scale of automation and information technology, by the supply of consultancy services or by efficient business environment. An important role for the innovativeness of the economy is also played by the stage of innovation commercialization in which an effect in the form of a new product, technology or organizational solution is obtained. Commercialization of innovations involves the application of risk capital. Measures stimulating allocation of risk capital as well as principles of pre-financing of research and development activities in Poland are still in their infancy. However, from a statistical point of view, the comparison of the share of these funds in the Polish economy with the United States and the European Union member states looks relatively favorably.

The share of risk capital in GDP can be the subject to comparison with regard to: early development finance and expansion financing.

Early development finance ${ }^{2}$ is a type of capital which is necessary after the start-up phase, first of all, at the beginning of industrial production of an innovative product and at the beginning of its sale. It also determines the growth of circulating capital, the demand for which increases intensively, for example after the launch of the product on the market. Expansion financing, on the other hand, is provided for the needs of large investments with the aim of developing a well-established company, building a new factory, extending the existing distribution network, increasing supply (in the case of seasonal sales), reducing debts of the company in the bank to safe levels etc. [12].

Fig. 10 shows levels of early development finance and expansion financing in Poland compared to the situation in the EU-15 and the USA.

\footnotetext{
${ }^{2}$ The return from early development investments is obtained usually after $3-7$ years [10].
} 


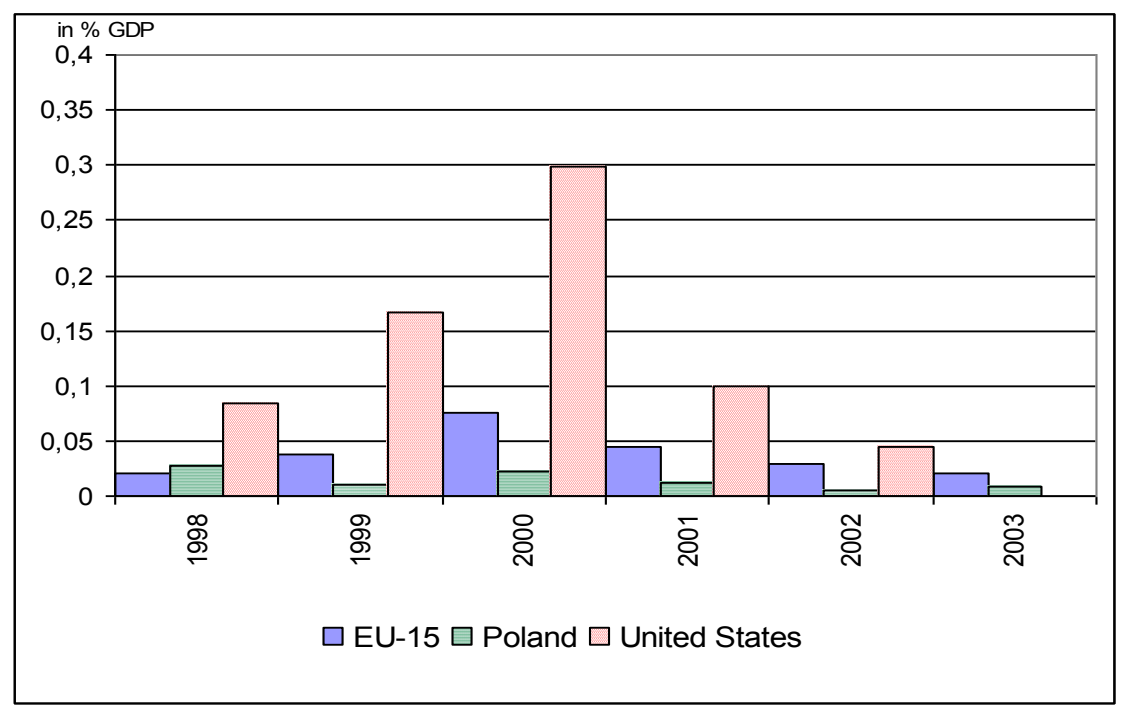

Fig. 10: Risk Capital, Early Development Finance in \% of GDP in Poland ${ }^{3}$, the EU-15 and the United States

In the analyzed period, the level of risk capital involved in the financing of the early development stage was on average eight times lower than in the United States.

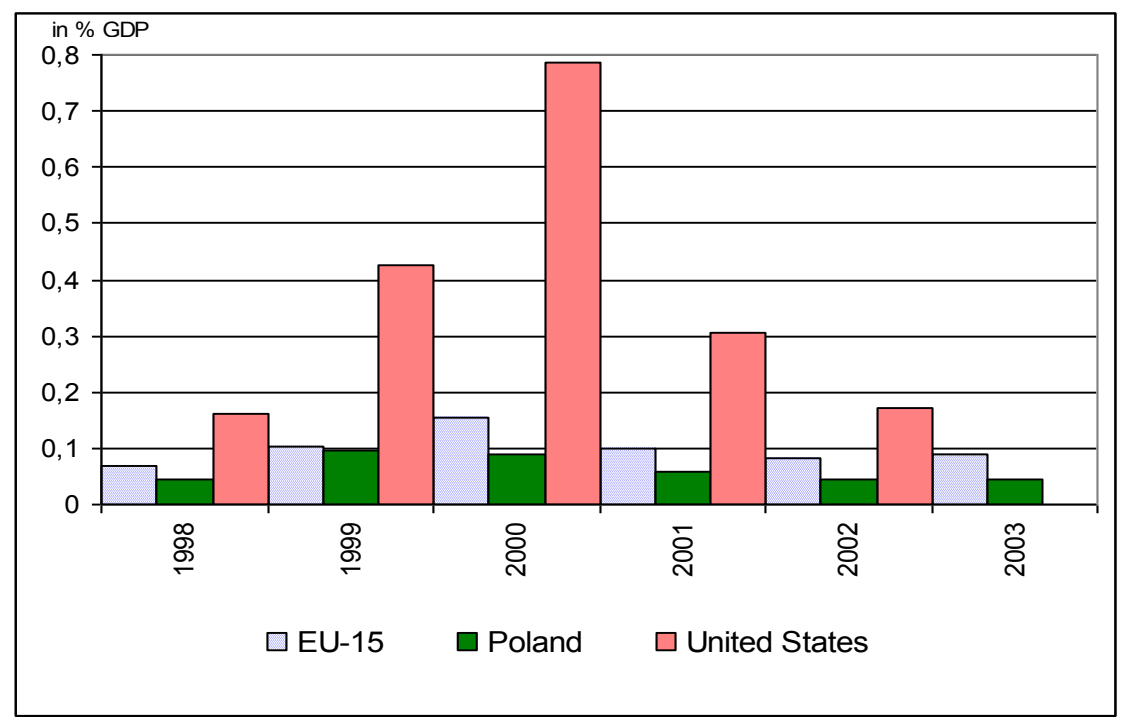

Fig. 11: Risk Capital, Expansion Stage Financing in \% of GDP in Poland, the EU-15 and the United States

Source: Own analysis on the basis of data from Eurostat [8]

${ }^{3}$ Available for Poland since 1998. 
In the studied period, the level of risk capital involved in the financing of the expansion stage was on average over five times lower than in the United States.

In the years 1998-2003 risk capital financing in Poland accounted, on average, for $0.078 \%$ of the GDP whereas the average for EU-15 was $0.137 \%$, which means a nearly two-times lower level. In the United States, on the other hand, the commercialization of innovations with the use of risk capital financing is a relatively common practice and its level in the years 1998-2001 was on average three times higher than in the EU-15.

The highest level of financing research by means of risk capital funds was recorded in the EU-15 and in Poland in 2000, which probably was the result of increased trust of companies in the assumptions of the Lisbon Strategy. In the following years a decrease in the interest in such form of financing was recorded.

\section{INNOVATIVENESS OF THE POLISH INDUSTRY}

An effective implementation of innovations in the industry is not only a simple reflection of the capital involved and advanced technologies applied, which results from the growth of the companies production potential. This effectiveness largely depends on non-technical factors, and in particular on absorption capabilities of companies.

Together with the globalization of the markets and the transfer of knowledge in the international dimension, the nature of a modern industrial company changes. Faster international diversification of manufacturing and research entities and necessity for the companies to participate in the process of technology transfer through the acquisition of technologies from external sources can be observed. Absorption of technologies and their integration with the industry development base is of primary importance for positive effects of the implementation of new technologies leading to the industry competitiveness growth.

Expenditures of the Polish industry on innovative activities are borne mainly by the private sector (81.7\%), which had $56.6 \%$ of the gross value of fixed assets in the industry in 2003. Fig. 12 presents the level of expenditures, in nominal value, on innovative activities incurred by the Polish industry and the growing trend of these expenditures.

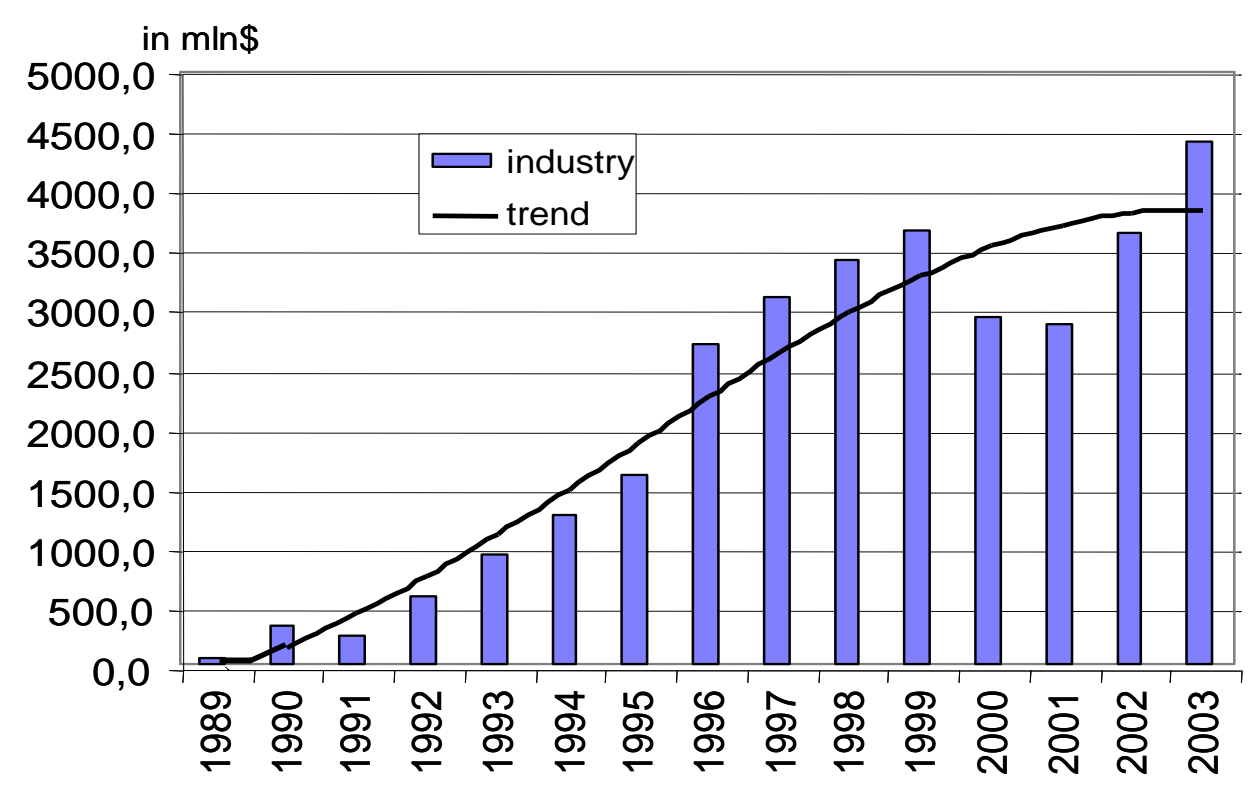

Fig 12: Expenditures on Innovative Activities in the Industry in the Years 1989-2003

Source: Own analysis on the basis of data from the Central Statistical Office (GUS) in Poland $[10,13]$ 
Huge differences between the beginning of the transformation process in the Polish economy and the year 2003, in expenditures on innovative activities in the Polish industry were determined by the fact that in 1989 only less than $10 \%$ of Polish industrial companies were introducing innovative solutions, and by the year 2003 this index increased to nearly $40 \%$. In the Polish manufacturing companies the basic item of expenditures on innovative activities and their main type (source of innovation) is purchase of machines and technical devices (61.2\%), that means the acquisition of a so-called tangible technology. On the other hand, R\&D activities are financed to a limited extent (11.6\%) (fig. 13).

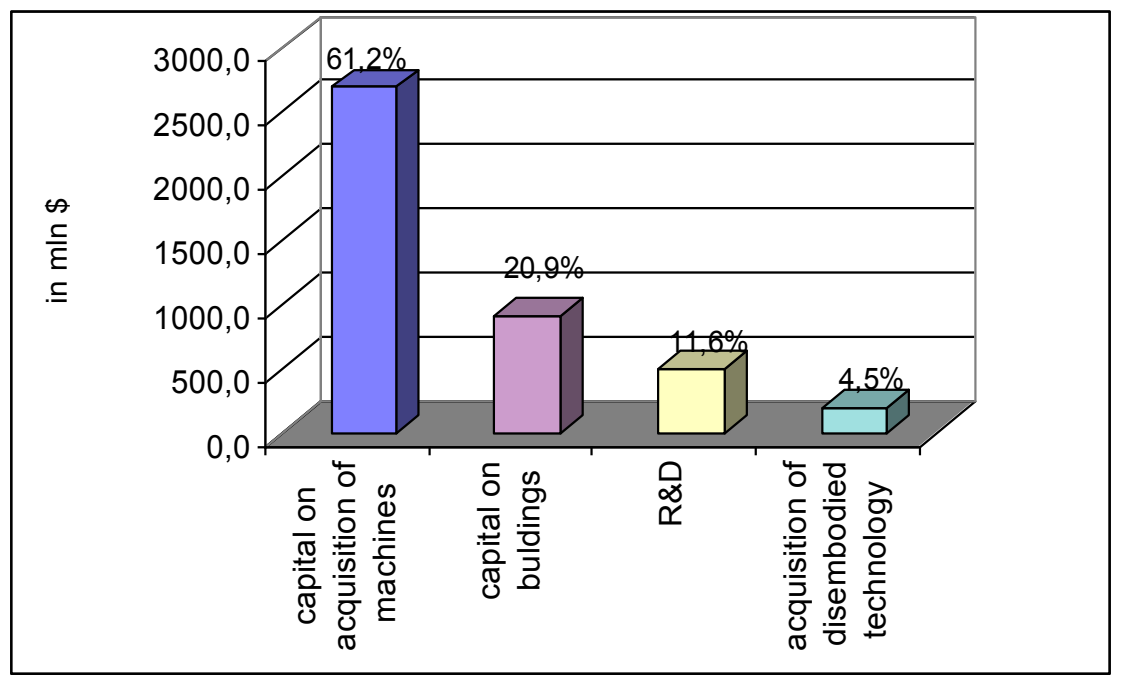

Fig. 13: Scale and Structure of Expenditures on Innovative Activities in the Polish Industry in 2003

Source: Own analysis on the basis of data from the Central Statistical Office (GUS) in Poland $[10,13]$

Considering the fact that the major part of expenditures on innovative activities in Poland is borne by the manufacturing sector (91.1\% in 2003), further analysis does not include mining and energy sectors, which together with the manufacturing, according to the European Classification of Activities, comprise the industry sector. In the field of manufacturing the sector of investment goods (W sector), representing the highest level of innovativeness of the Polish industry, was chosen as a subject of a detailed analysis ${ }^{4}$ : (Table 1).

Analysis of two periods, i.e. 1998-2000 and 2001-2003 indicates that on the background of the Polish industry the sector of investment goods had the highest share of innovative companies and the highest dynamics of the growth of expenditures on innovations.

\footnotetext{
${ }^{4}$ This division is based on the Polish Classification of Activities (in force since 2001) which is a modification of the European Classification of Activities. K sector comprises the following branches of production: manufacture of food products and beverages, manufacture of tobacco products, manufacture of textiles, manufacture of wearing apparel and furriery, processing of leather and manufacture of lather products, manufacture of furniture; manufacturing n.e.c. P sector comprises: manufacture of coke, refined petroleum products, manufacture of wood and wood, straw and wicker products, manufacture of pulp and paper, manufacture of other non-metallic mineral products, manufacture of basic metals, manufacture of metal products. W sector comprises: manufacture of chemicals and chemical products, manufacture of rubber and plastic products, manufacture of machinery and equipment n.e.c., manufacture of office machinery and computers, manufacture of electrical machinery and apparatus n.e.c., manufacture of ratio, television and communication equipment and apparatus, manufacture of medical, precision and optical instruments, watches and clocks, manufacture of motor vehicles, trailers and semi-trailers, manufacture of other transport equipment, recycling [6].
} 
Table 1: Changes in the Innovative Activities of the Polish Industry

\begin{tabular}{|l|c|c|c|}
\hline & \multirow{2}{*}{$\begin{array}{c}\text { Dynamics of expenditures on innovative } \\
\text { activities in 2003 }(1998=100 \%)\end{array}$} & $1998-2000$ & $2001-2003$ \\
\cline { 3 - 4 } & 178 & 16.9 & 39.3 \\
\hline Industry & 187 & 16.7 & 40.3 \\
\hline Manufacturing & 293 & 26.2 & 50.8 \\
\hline
\end{tabular}

Source: Own analysis on the basis of data from the Central Statistical Office (GUS) in Poland [10, 13]

In W sector, like in the Polish industry in general, dynamic changes with regard to the share of expenditures on innovations in the group "machines" occurred (fig. 14).

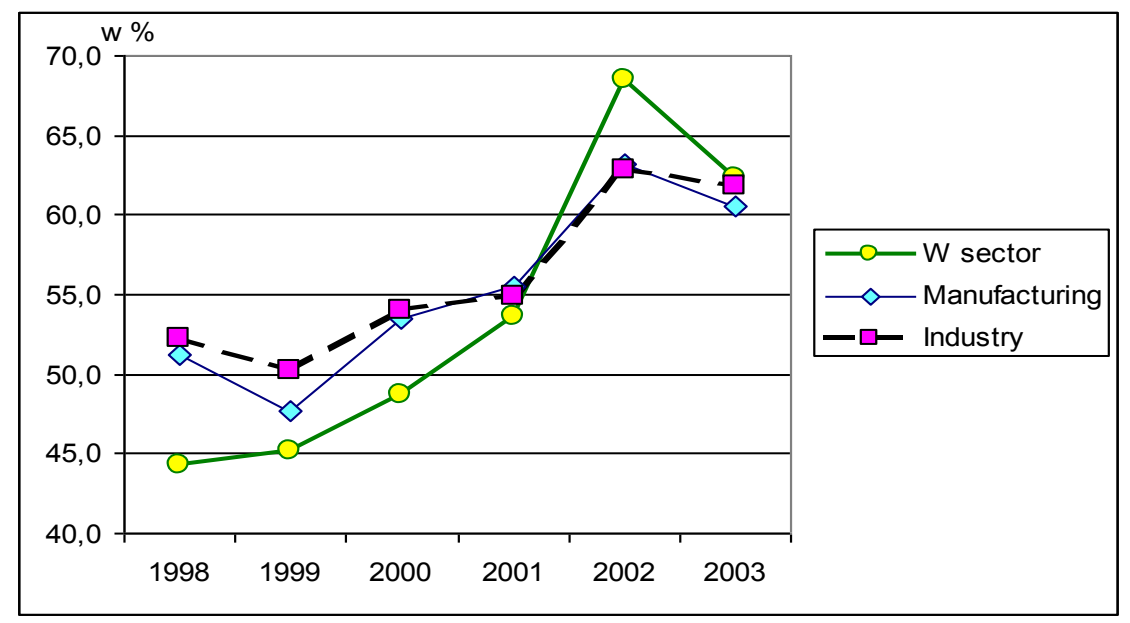

Fig. 14: The Share of Expenditures on Innovations in the Group "Machines" in Comparison to Total Expenditures on Innovations in Poland Source: Own analysis on the basis of data from the Central Statistical Office (GUS) in Poland [13]

In the Polish industry the value of the purchases of imported machines grew radically at the turn of 1999 and 2000 and in the following years it has maintained at a quite high level of about $40 \%$ (tab. 2).

Table 2: Value and Shares of Imported Machinery in the Industry, in US Dollars

\begin{tabular}{|l|c|c|c|c|c|c|}
\hline Years & 1998 & 1999 & 2000 & 2001 & 2002 & 2003 \\
\hline In US dollars & 408.8 & 463.7 & 662.3 & 752.0 & 731.2 & 1129.5 \\
\hline $\begin{array}{l}\text { Percentage share of imported } \\
\text { machines in the total } \\
\text { expenditures on machines }\end{array}$ & 22.9 & 25.1 & 41.5 & 47.6 & 32.0 & 41.3 \\
\hline
\end{tabular}

Source: Own analysis on the basis of [10]

An increasing share of investments in machines in total expenditures on innovations and a growing share of imported machines prove that national science sector is not perceived as an attractive partner for the industry (fig. 13, 14). 
Financial barriers and a relatively long process of innovations commercialization developed in the national research sector determine a decreasing trend in the expenditures on R\&D in the industry, and in particular in the sector of investment goods (fig. 15).

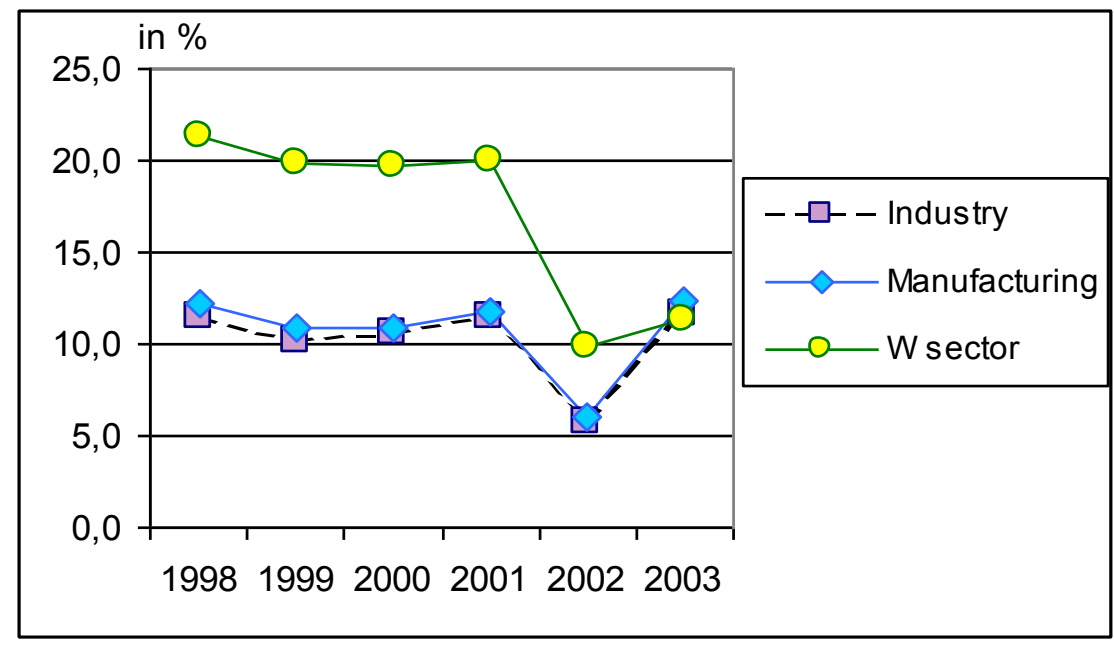

Fig. 15: Changes in the share of expenditures on R\&D in the expenditures on innovative activities in W sector against the background of the industry in general

Source: Own analysis on the basis of [13]

Moreover, the intensity of R\&D activities in the sector of investment goods decreases, although it is still on average higher than in the manufacturing sector and in the industry in general (fig. 16).

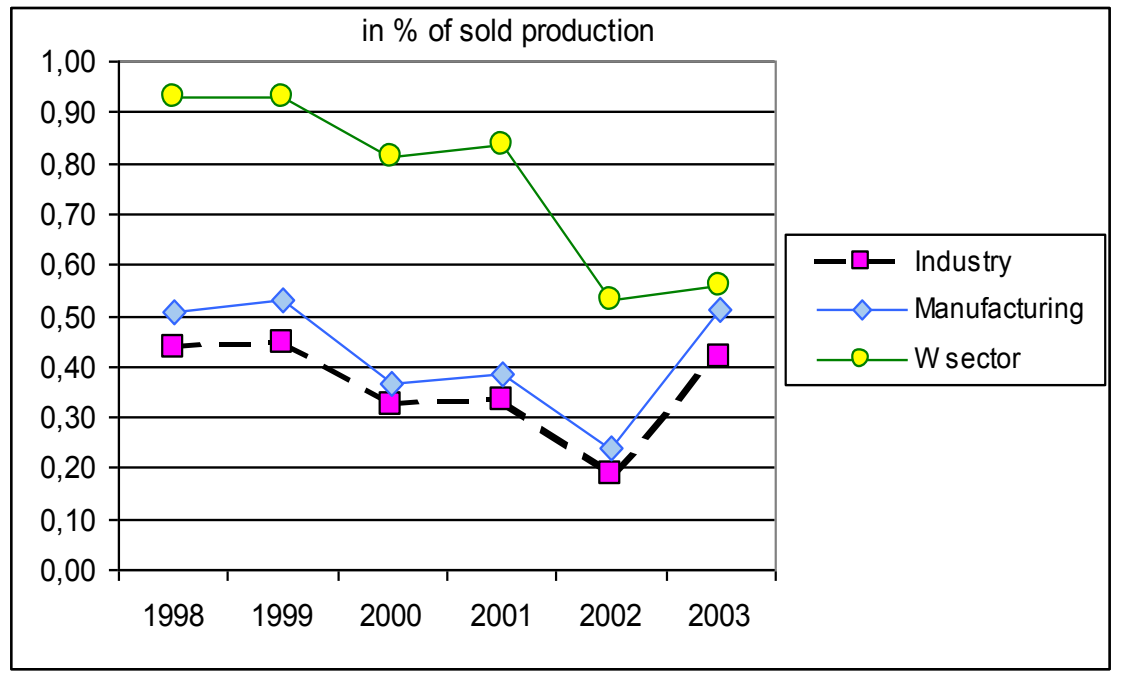

Fig. 16: Intensity of Expenditures on R\&D in W Sector Against the Changes in the Industry

Source: Own analysis on the basis of [13] 
Taking into account the share of innovative companies and the scale of expenditures on innovative activities, the branch of mechanical vehicles production as well as machines and devices production are the unquestionable leaders in terms of innovativeness in the Polish sector of investment goods (fig. 17). In both these branches the share of innovative companies exceeds the average level for the investments goods sector and amounts to over 50\%.

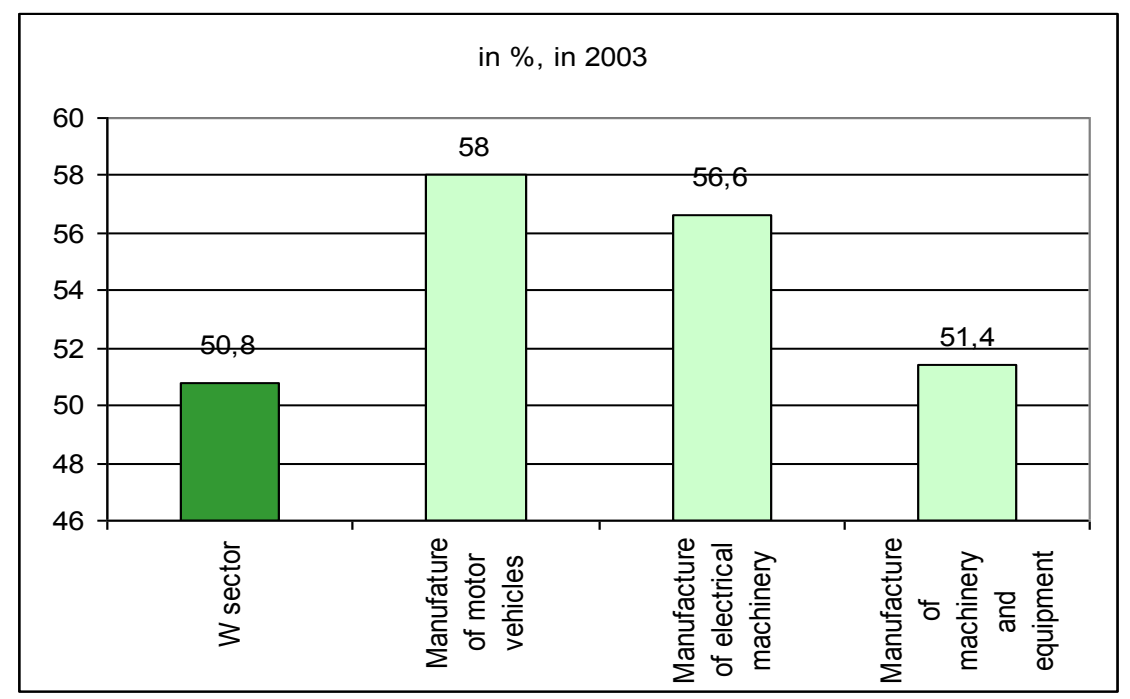

Fig. 17: Innovation Leaders in the Sector of Investment Goods in 2003 Source: Own analysis on the basis of [13]

The results of the implementation of new technologies are to a large extent influenced by the index of expenditures on innovative activities per one company. Taking the aforementioned index as a determinant of innovativeness, the sector of mechanical vehicles production is the unquestionable leader of innovativeness (fig. 18).

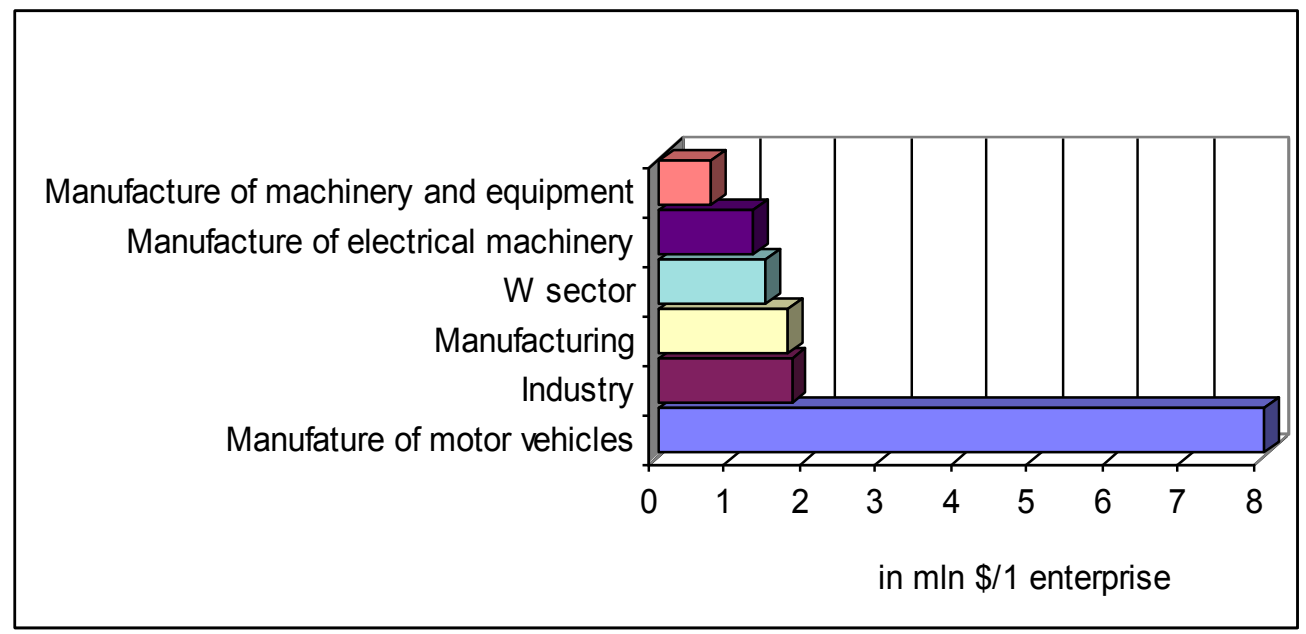

Fig. 18: Innovation Leaders According to the Criterion of Expenditures on Innovative Activities Per One Company

Source: Own analysis on the basis of [13] 
The chosen criteria enabled to consider the branch of mechanical vehicles production to be a leader of investment goods sector. This branch was characterized by nearly six times higher expenditures on innovations than the average for the sector and higher share of innovative companies.

\section{CONCLUSIONS AND REMEDIAL MEASURES INTRODUCED IN POLAND}

In Poland a non-typical dichotomy can be observed: on the one hand a constant decline of expenditures on R\&D works, mainly in financing from the state budget, and on the other hand a dynamic increase of financial means allocated for the innovativeness development in the economy, stemming particularly from the industry. This phenomenon was affected by the policy applied recently, oriented mainly to investment purchases (including a huge import) of modern machines and to significant extension of the share of innovative enterprises in the national economy. In enterprises from almost exclusively private sector, equipped with modern production means a great need for product, process and organizational innovations has arose recently. The Polish R\&D sector that has been financed on constantly lowering level is not able to meet neither this increasing industry demand nor the quality requirements of expected innovative solutions that should be in accordance with the world standards. In this respect some trends aiming at strengthening the R\&D sector are observed. They are outlined in the national plans of the Polish economy development, coming into effect in 2006, and foresee a change in financing R\&D from the state budget and in particular from business.

An important element strengthening the R\&D sector in Poland is also the participation in projects connected with Poland's EU accession, in particular those funded within the framework of structural funds: „Improvement of Competitiveness of Enterprises” and „Human Resources Development” as well as active participation in the process of creating the European Research Area. Polish scientific and research circles have shown a great interest in the $6^{\text {th }}$ Framework Program of the EU. The number of submitted research projects proposals amounted to $4 \%$ and with this score Poland holds the $10^{\text {th }}$ position among all the EU member states ( $1^{\text {st }}$ position among the new EU member states). As to the number of projects maintained for realization Polish researcher teams participate in $2.5 \%$ projects and this is also a very meaningful - eleventh position among the EU member states (also $1^{\text {st }}$ position among the new EU member states). The official documents of the European Commission [Position Paper Mid-term assessment FP6-TP3 „Nanotechnology and Nanosciences, Knowledge-based Multifunctional Materials, New Production Processes and Devices"] emphasize the significant position of the new EU member states, in particular Poland, in the execution of priority directions of research putting a great stress on the fact that they "have centers of excellence in materials science and nanotechnology, which significantly enhance Europe's capability. These countries offer potential opportunities for creation of new manufacturing facilities". Also the other scientific and research directions constituting the European policy of sustainable development, such as e.g.: environmental protection, energy and materials saving, innovativeness development in the field of new products and manufacturing processes have a great tradition and modern development backup facilities in Poland. Current initiatives in this area comprise first of all the creation of strategic governmental program "Improvement of systems of innovativeness development in production and maintenance 2004-2008" and establishing a national Institute (Institute for Terotechnology - National Research Institute in Radom) dealing with innovativeness issues in the field of sustainable development of the national economy.

Very unfavorable official statistics on the innovativeness of the Polish economy and, in particular, of the R\&D sector, presented in this paper, do not find, according to the authors, full confirmation in the reality which seems to be significantly better than the statistical data indicates. This is influenced by such factors as strong Polish currency and traditionally very low, comparing to the United States, EU and Japan, salaries of the R\&D staff, which usually are the major cost of scientific and research activities. It seems that conditions for the development of innovativeness of the Polish economy are at the stage of overcoming unfavorable tendencies and that positive trends that appear will enable Polish companies to successfully compete on national and global markets. 


\section{REFERENCES}

1. Bartosik M., Kleiber M., "Okoń-Horodyńska E., Regionalne strategie innowacyjne jako element polityki naukowej w przededniu integracji europejskiej" http://www.rislodzkie.lodz.pl/IForum/Prezentacje/ Kleiber.ppt, March 2004.

2. Bartosik M., Założenia polityki naukowej, naukowo - technicznej i innowacyjnej państwa a Narodowy Plan Rozwoju 2007 - 2013, Konferencja „Budowa Gospodarki Opartej na Wiedzy”, Warsaw 27.10.2004.

3. Baruk J., Innowacje a rozwój gospodarczy, Problemy Jakości 2004, nr 4, p. 30.

4. Chmiel J., Stan sektora MSP w 2002 roku. Tendencje rozwojowe w latach 1994-2002. PARP, Warsaw 2004.

5. $\quad$ Czupiała J., Ekonomika innowacji, AE, Wrocław 1994, p. 25-26.

6. Dobrodziej J., Mazurkiewicz A., Sitkowska R., "Innovative activity and change tendencies of some of Polish industry's economic indicators", Journal of Business and Economics Research 2004, v. 2 nr 6, p. 9-20.

7. European competitiveness report, European Commission, Commission staff working document, SEC (2004)1397.

8. "Investissement en capital-risque" (phase préliminaire et expansion et replacement). Pourcentage du PIB. Eurostat, http://europa.eu.int/comm/eurostat

9. "Innovation dans l'UE. Communiqués de presse" d'Eurostat sur Internet: 61/2004 - 7 mai 2004, http://europa.eu.int/comm/eurostat/

10. Nauka i technika 2000-2003, GUS, Warsaw 2001-2004.

11. OECD Science, "Technology and Industry Scoreboard 2003 -Towards a knowledge-based economy", http://www1.oecd.org/publications/e-book/92-2003-04-1-7294/A.2.htm

12. Pawlak W.R., "Kapitał wysokiego ryzyka (Venture Capital) a Parki Technologiczne", Innowacje nr 5, imik.wip.pw.edu.pl/innowacje5/strona10.htm

13. Rocznik Przemysłu 1993-2004, GUS, Warsaw 1994-2005. 


\section{NOTES}

